\title{
Passives in South Asian Languages
}

\section{Pritha CHANDRA}

Indian Institute of Technology Delhi

prithachandra@gmail.com

\author{
Anindita SAHOO \\ Indian Institute of Technology Delhi \\ sahoo.anindita@gmail.com
}

\begin{abstract}
Haspelmath (2010) debates whether universal (descriptive) categories of the types that generativists (cf. Newmeyer, 2007) envisage are real and needed for cross-linguistic studies. Instead every language has its own unique set of categories. We raise doubt on this "categorial particularism" position by drawing on underlying similarities of passive constructions of three South Asian languages - Oriya (Indo-Aryan), Malayalam (Dravidian) and Kharia (AustroAsiatic). Unlike English-type passives, they retain subject properties for their logical subjects and object properties for their logical objects, suggesting commonalities that a "categorial particularism" approach would not allow us to posit. Our further contention is that like English passives, they too satisfy Shibatani's (1985) minimal condition for passives - the underscoring or the optionality of agents. Passive voice must therefore be a universal found in all languages primarily resulting in the optionality of agents. We also show how adopting this approach helps us re-analyse Meitei and Ao (Tibeto-Burman) as languages involving passives.
\end{abstract}

Keywords: active-passives; universals; comparative concepts; descriptive categories; South Asian languages

\section{Izvleček}

Haspelmath (2010) se v svoji razpravi sprašuje, ali so univerzalne kategorije, ki jih obravnavajo generativisti (prim. Newmeyer, 2007), resnične in potrebne za medjezikovne raziskave. Namesto tega naj bi imel vsak jezik svoje lastne kategorije. Članek se ne strinja s konceptom "specifičnih kategorij", kar prikaže na primeru podobnih pasivnih konstukcij v treh jezikih Južne Azije: v indoarijskem jeziku orija, dravidskem jeziku malajalam in avstroazijskem jeziku karija. Z razliko od pasivov, ki so značilni za angleščino, pasivi v teh jezikih ohranjajo značilnosti osebka za logične osebke in značilnosti predmeta za logične predmete. V okviru koncepta "specifičnih kategorij" to ne bi smelo biti mogoče. Sledi utemeljitev, da enako kot v angleščini tudi tu omenjene oblike pasiva ustrezajo mininalnim pogojem za pasiv, kot jih določa Shibatani (1985), t.j. poudarek na neobveznem vršilcu dejanja. Pasiv torej mora biti univerzalna značilnost vseh jezikov, ki se sprva kaže skozi neobvezni vršilec dejanja. Članek nazadnje pokaže, kako lahko s tem pristopom ponovno analiziramo tibetansko-burmanska jezika Meitei in Ao, kot jezika v pasivom.

Ključne besede: aktivni pasiv; univerzalije; koncepti primerjave; opisne kategorije; jeziki Južne Azije

Acta Linguistica Asiatica, 3(1), 2013.

ISSN: 2232-3317, http://revije.ff.uni-lj.si/ala/

DOI: $10.4312 / a l a .3 .1 .9-28$ 


\section{Introduction}

Generative linguistics is defined by its assumption of universals, the idea that there is a substantial set of categories such as adjectives, passive voice, accusative case etc. available cross-linguistically (Newmeyer, 2007). The "categorial universalist" approach allows linguists to compare languages at the level of categories and is widely accepted amongst generative typologists (Payne, 1997; Corbett, 2000; Van Valin, 2005; Dixon 2010). There are two perspectives with regard to universals. The first is that languages make their own selections from a universal set of features, constructing categories that may not be available cross-linguistically. However, if they have some category (say adjectives), this category will exist in the same sense as it is present in all other languages (cf. Newmeyer). A second and a more radical approach to universals, assumes that particular categories are universal not only in the sense of being universally available, but also of being universally instantiated (Baker, 2003; Dixon, 2004). As illustration, the "verb-object" constraint that combines the verb with its object to form a linguistic unit without the subject is assumed a true linguistic universal (Baker, 2009), but confirmed by different languages in varied ways.

A diametrically opposite view to universalism held by some typologists is that there are no universal "descriptive categories" common across languages; each language has its own unique set of categories that are in principle, non-comparable across languages (cf. Haspelmath, 2007, 2010). Grammatical categories are not crosslinguistic entities (either universally available or universally instantiated). To undertake comparative studies therefore, typologists construct "comparative concepts" (e.g. passive voice, subject etc.) that are usually based on some semantic content. These concepts are thus theoretical constructs, not real objects in the world's languages.

In this paper, we place a typological study of passives of South Asian languages/SALs against the universalism/particularism debate. ${ }^{1}$ It has been noticed by Mahajan (1994) that Hindi passives are different in that they neither demote their subjects nor promote their objects as subjects. Here, we show that these properties are also true for many other South Asian languages. The absence of English-type passives in Hindi, and other SALs could be taken to indicate that there is no universal passivevoice category to be compared across languages. This together with the observation (Shibatani, 1985) that many Sino-Tibetan languages (especially Phillipine-type languages) lack prototypical passives would argue strongly against positing a universal linguistic category for passive.

However, we claim, based on similarities between languages of three different families (Austro-Asiatic, Dravidian and Indo-Aryan) that passive voice is available to even those languages that fail to host English-type passives. The passive head helps underscoring the agents - the minimal condition for passives (Shibatani, 1985) - in SAL passives, just like it does in English. We also discuss data from SALs like Meitei and Ao (Tibeto-Burman) that are generally assumed to lack passives, presenting novel evidence with underscored agents in some otherwise active looking constructions.

The paper is organized as follows. We start section two with some widely accepted properties of passives. This is followed by section three where we illustrate

\footnotetext{
${ }^{1}$ We restrict ourselves to regular passives with transitive verbs in this paper.
} 
how SAL passives differ from their English counterparts. In the next section, Meitei and Ao are shown to host passives. The final section concludes the paper with some observations on the universalist and particularist debate.

\section{Canonical Passives}

It is generally agreed that a passive has the following properties (Givon, 1979; Siewierska, 2005; Shibatani, 2006; Comrie, 1989):

i) It contrasts with another construction, the active.

ii) The subject of the active corresponds to a non-obligatory oblique phrase of the passive or is not overtly expressed (but only implied).

iii) The subject of the passive, if there is one, corresponds to the direct object of the active.

iv) The construction displays some special morphological marking of the verb.

v) The construction is pragmatically restricted relative to the active.

A typical example of a regular passive vis-à-vis its active counterpart is given in (1)-(2).

(1) John saw Mary.

(2) Mary was seen (by John).

There are two noticeable differences between the active and the passive forms: in the passive, (i) the agent is underscored and (ii) the theme is highlighted, exactly opposite of what we find in the active. While the active agent cannot be deleted and is the canonical subject, the passive agent is optional and introduced by a "by-phrase". According to Shibatani (1985), agent underscoring (or its optionality) is a minimal condition for passives; all passives must meet at least this formal condition. A second property for passives is that the object, which is the theme of the active, occupies the subject position in the passive and becomes the most prominent argument of the construction. In semantic terms, this leads to the formation of a consequent result or inchoative state depicting a topicalized object (see Gehrke \& Grillo, 2009). In short, the theme-rheme relation of the active is distorted in the passive (Granger, 1983).

Most scholars take both properties - subject demotion and object topicalization (or its promotion to subject position) - as the two canonical properties defining passives cross-linguistically. Generative syntax treats passivization as an operation on argument structure involving the promotion of the internal argument to the subject position and demotion of the external argument to an adjunct position. Baker, Johnson and Roberts (1989) in their pioneering study, suggest that these changes are brought about by the en-morpheme introducing a third argument in the structure. This extra argument gets the external theta-role originally due to the agent and the accusative case value of the verb, otherwise assigned to the internal argument. The former is therefore forced to surface as an (optional) adjunct and the latter as the subject of the sentence, receiving a nominative case. Schematically (3): 
(3) $\left[\mathrm{Obj}_{\mathrm{j}}[\mathrm{V}\right.$-en (+ext. $\theta,+$ acc.case $\left.) \mathrm{t}_{\mathrm{i}} \mathrm{t}_{\mathrm{j}}\right]$ by-Subj $\left.\mathrm{i}\right]$

Passives in several languages attest to both these properties. Some relevant examples are provided below for illustration.

(4) Der lower wurde von ihm getotet

the-nom. lion-nom. became by him killed-p.part.

"The lion was killed was him."

(German, Siewierska 1984)

(5) Billettene fas av publikum i luken

tickets-the get-s by audience-the in window-the

"The tickets are got by the audience in the window."

(Norwegian, Afarli 1992)

(6) C'a domashn'a robota bula napysana neju

This-nom. home.nom. work.nom. be.pst. write.part.nom by her

"This homework was done by her."

(Ukranian, Slavutych, 1973)

\section{Non-Canonical Properties of Passives}

Unlike English and other languages, passives in some South Asian languages are not distinguished by both agent underscoring and object to subject promotion. Mahajan (1994) was the first to point out that though Hindi agents surface as by-phrases in passives, they retain all prototypical subject properties. Passive objects on the other hand are not derived subjects; they display all prototypical properties of active objects (also see Bhatt, 2003; Richa, 2011).

To illustrate:

$\begin{array}{llll}\text { (7) raavan yuddh mein (raam dwaaraa) } & \text { maaraa } & \text { gayaa } \\ \text { Ravan battle in (Ram by) } & \text { kill-PFV } & \text { go-PFV } \\ \text { "Ravan was killed in the battle by Ram." } & & \end{array}$

This sentence is a Hindi passive, where the internal argument of a transitive verb maar ("kill") seemingly surfaces as the subject of the sentence, while the agent becomes an optional adjunct, marked by dwaaraa. The verb is in its agreeing perfective participial form $a a$, followed by the auxiliary verb yaa ("go").

Mahajan claims that despite appearances (7) is only passive-like in that it differs in important respects from English-type passives. He terms it and similar others as Active Passives, observing their commonalities with their active counterparts. Active passives, like their active counterparts have logical subjects/agents (dwaaraa-DPs) with subjecthood properties and logical objects with object-hood properties. There is however a difference in the verbal morphology, just as we would expect of passives and the agents become optional. 
Mahajan uses diagnostics like anaphor binding, pronominal co-reference and control (drawing on works by Keenan (1976) among others) to substantiate his claim on passive subjects. Consider:

(8) a. salmaa apne $_{i}$ ghar kaa niriksan karegi

Salma self's home GEN examination do-FUT-FEM

"Salma will examine self's house."

b. salmaa dwaaraa apne $_{\mathrm{i}}$ ghar kaa niriksan kiyaa gayaa Salma by self's home GEN examination do-PFV go-PFV ${ }^{2}$ "Salma will examine self's house."

Possessive reflexive binding is a subject property in Hindi. In the active (8a), the possessive reflexive apne is bound by the matrix subject salmaa. The situation remains exactly the same in the passive (8b); the agentive by-phrase of the passive salmaa dwaaraa also binds the possessive reflexive. Similarly, agentive by-phrases also fail to co-refer to pronominal DPs in the structure, a condition known as "anti-subject orientation". Both active and passive logical subjects pattern alike in this regard, as illustrated below in (9a)-(9b).

(9) a. salmaa uske $_{*}$ ghar kaa niriksan karegi

Salma her home GEN examine do-FUT-FEM

"Salma will examine her house."

b. salmaa $_{\mathrm{i}}$ dwaaraa uske $_{*_{\mathrm{i}}}$ ghar kaa niriksan kiyaa gayaa Salma by her home GEN examine do-PFV go-PFV "Her house will be examined by Salma."

Yet another subject property of Hindi is that its subjects can control into complement clauses (10a). Agentive by-phrases in passives have the same ability (10b).

(10) a. salmaa ${ }_{i}\left[\mathrm{PRO}_{\mathrm{i}}\right.$ ghar jaanaa chaahti thi Salma home go-INF want-IMP-FEM be-PST-FEM "Salma wanted to go home."

b. salmaai dwaaraa $\left[\mathrm{PRO}_{\mathrm{i}}\right.$ ghar jaanaa] chaahaa gayaa alma by home go-INF want-IMP go-PFV "Salma wanted to go home."

Moreover, both active and passive subjects may also control into conjunctive participle adverbial clauses in the language (11a)-(11b).

(11) a. salmaa ${ }_{i}\left[\mathrm{PRO}_{\mathrm{i}}\right.$ ghar jaa kar $]$ mohan ko daategi

Salma home go ConjPrt Mohan ACC scold-FUT-FEM

"Salma will scold Mohan after going home."

${ }^{2}$ Richa (2011) uses "PFV" to gloss the past form of the passive morphemes in Hindi; we follow her here. 
b. salmaa dwaaraa $\left[\mathrm{PRO}_{\mathrm{i}}\right.$ ghar jaa kar ] mohan ko daataa gayaa Salma by home go ConjPrt Mohan ACC scold-PFV go-PFV "Mohan was scolded by Salma after she went home."

Agentive by-phrases in Hindi passives bind possessive reflexives, show antisubject orientation, control into complement and adverbial clauses, thereby depicting all prototypical subject properties of the language.

Furthermore, Mahajan provides evidence to show that the object in the Active Passive behaves just as it does in an active construction. Consider (12a)-(12c).

(12) a. raajaa ne saare shero ko maar diyaa

king ERG. all tiger-PL ACC kill give

"The king killed all the tigers."

b. raajaa dwaaraa saare shero ko maar diyaa gayaa king by all tiger-PL ACC kill-PFV give-PFV go-PFV

"All the tigers were killed by the king."

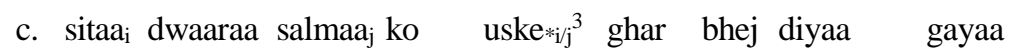
Sita by Salma ACC her home send give-PFV go-PFV "Salma was sent to her home by Sita"

d. raam dwaaraa $\operatorname{mohan}_{\mathrm{i}}$ ko $\left[\mathrm{PRO}_{\mathrm{i}}\right.$ ghar jaane ke liye] kaahaa gayaa Ram by Mohan ACC home go-INF GEN for tell-PFV go-PFV "Mohan was told by Ram to go home."

In the passive construction (12b), the logical object saare shero retains the accusative $k o$ of the active object (12a). Apart from that, the pronoun in the passive construction (12c) can co-refer with the object. This suggests that the passive object is also the grammatical object because had it been in a subject position, it would have shown anti-subject orientation. Interestingly, the passive object can control into the complement clause, indicating that it has moved to a position high enough to ccommand the embedded subject (12d). However, that position is not the subject position of the Active Passive.

Contrary to Mahajan, Bhatt (2003) claims that non-case marked objects (minus ko) are promoted in passives, which are attested by the nominative case on them; compare (13a) and (13b).

(13) a. mujh ko fouran pehchaan liyaa jaayegaa me-OBL-ACC immediately recognize take-PFV go-PFV-FUT "I will be recognized immediately."

b. me fouran pehchaan li jaaungi

I immediately recognize take-PFV go-PFV-FUT.F

"I will be recognized immediately."

\footnotetext{
${ }^{3}$ The pronominal can also refer to any arbitrary person.
} 
But Bhatt's claims for object movement to subject position are not wellsubstantiated. Richa (2011) presents evidence from control indicating quite the contrary. As shown in (14a)-(14b), both objects, with or without ko case, fail to control into the conjunctive participial clauses, a fiat only possible for real subjects.

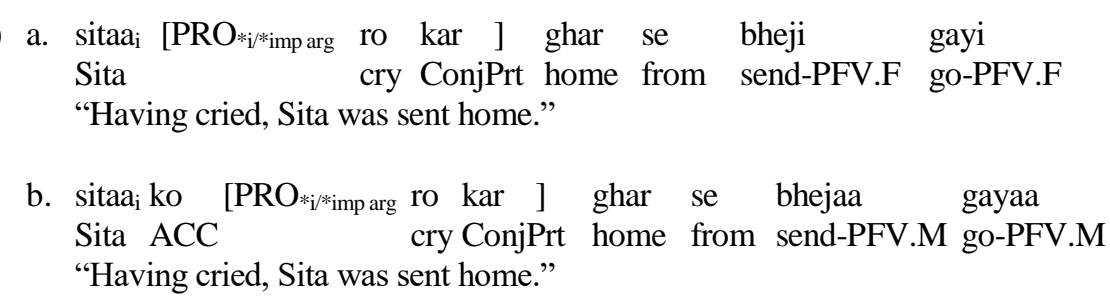

But these two differently marked objects clearly have different landing sites. This difference is witnessed by the ability of only overtly case-marked objects to bind pronominals (15a) versus (15b), suggesting that only these DPs are placed high enough to A-bind other DPs.

(15) a. chuhe ko uske $e_{j / k}$ beg me rakhaa gayaa
rat ACC his bag in keep-PFV go-PFV
"The rat was kept in his bag."
b. chuhe $_{\mathrm{j}}$ uske $_{*_{\mathrm{j} / \mathrm{k}}}$ beg me rakhaa gayaa rat his bag in keep-PFV go-PFV
"The rat was kept in his bag."

To summarize, Hindi regular passives have two salient properties. The first is that the external argument which is an agentive phrase retains subject properties though it surfaces as a PP. The second property is that the ko marked object is in a higher position than the unmarked one, though neither occupies the subject position of the clause.

\subsection{Oriya Active Passives}

As with Hindi, Oriya regular passives don't differ much from English-type passives, at least going by the surface structure. The internal argument of a transitive verb appears as the subject of the sentence with the logical subject appearing as an adjunct introduced by a preposition dwaaraa ("by"). The verb is in its agreeing perfective participial form, followed by the light verb galaa, ("go"). A typical passive construction from Oriya is provided below (16b) with its active counterpart (16a).

(16) a. Mili raam ku juddh re maari delaa Mili ram ACC battle in kill-PFV give-PFV

"Mili killed Ram in the battle."

b. (mili dwaaraa) raam juddh re maraa galaa Mili by ram battle in kill-PFV go-PFV "Ram was killed in the battle (by Mili)." 
However the picture changes drastically once we start probing deeper into the structures. The first diagnostic - anaphor binding - shows that the agentive by-phrases are capable of A-binding reflexives, a property very reminiscent of active subjects. This similarity is illustrated between the active (17a) and the passive (17b).

(17) a. salmaa ${ }_{i}$ taa-nija $a_{i}$ ghara nirikshyana kalaa Salma self home examine do-PFV "Salma examined her house."

b. salmaa ${ }_{i}$ dwaaraa taa-nija $a_{i}$ ghara nirikshyana karaa galaa Salma by self home examine do-PFV go-PFV "Self's house was examined by Salma."

Moreover, like active subjects (18a), agentive by-phrases in passives also show anti-subject orientation (18b).

(18) a. salmaa $a_{i}$ taa $*_{i}$ ghara nirikshyana kalaa

Salma her home examine do-PFV

"Salma examined her house."

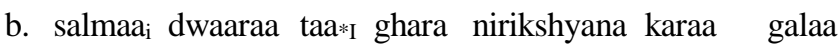

Salma by her home examine do-PFV go-PFV

"Self's house was examined by Salma."

While agentive by-phrases behave as subjects, passive objects retain the object properties of the language, as illustrated below.

(19) a. raajaa dwaaraa sabu baaghanku maari diaa galaa king by all tiger-PL-ACC kill-PFV give-PFV go-PFV

"All the tigers were killed by the king."

b. sitaa dwaaraa salmaa ko taa $a_{i}$ ghar ku pathei diaa galaa Sita by Salma ACC her home to send give-PFV go-PFV "Salma was sent to her home by Sita."

In (19a) the passive object retains the $k u$ accusative case marker. Sentence (19b) illustrates that a pronominal in a passive can co-refer with the object, which is quite different from what we witness with subjects. Case-marking on the object is however optional (20a)-(20b), similar to what we observe for Hindi.

(20) a. mote atishighra chihni diaa jiba me-OBL-ACC immediately recognize give-PFV go-PFV-FUT "I will be recognized immediately."

b. mu atishighra chihnaa padi jibi I immediately recognize fall-PFV go-PFV-FUT "I will be recognized immediately."

In Oriya too, we find clear syntactic differences between the marked and the unmarked ones, with only the former co-referring to possessive pronominals in the 
structure (21a)-(21b). This indicates that marked objects are placed higher than the unmarked ones.

(21) a. sitaa taa $_{*} \mathrm{i}_{j}$ ghar paakhare dekhaa galaa

Sita her-OBL-GEN home near see-PFV go-PFV

"Sita ${ }_{i}$ was seen near her home."

b. sitaa $\mathrm{ku}$ taa $\mathrm{i}_{\mathrm{j}}$ ghar paakhare dekhaa galaa

Sita ACC her home near see-PFV go-PFV

"Sita was seen near her home."

The marked ones can also control into adjunct clauses (22a)-(22b).

(22) a. sitaa ${ }$ [PRO $*_{i / i m p a r g}$ kaandu kaandu] gharu bidaa karaagalaa Sita crying crying home send do-PFV

"Sita was sent from home while she was crying."

b. sitaa $_{\mathrm{i}} \mathrm{ku} \quad\left[\mathrm{PRO}_{\mathrm{i} / \mathrm{mp} \text { arg }}\right.$ kaandu kaandu $]$ gharu bidaa karaagalaa sita ACC crying crying home send do-PFV

"Sita was sent from home while she was/people who sent her were crying."

However, these facts cannot be taken to claim that the marked object has moved as high as the subject. Evidence for a non-subject position for the raised object comes from control effects into conjunctive participles marked by the suffix kari on a bare verb stem. This conjunctive participle is the root of the verb karibaa and it obligatorily requires an overt controller in subject position (23).

$$
\begin{array}{lll}
\mathrm{ciku}_{\mathrm{i}} \quad \mathrm{monu}_{\mathrm{j}} \mathrm{ku} \quad\left[\mathrm{PRO}_{\mathrm{i} /{ }^{*}}\right. & \text { hasikari }] \text { maarilaa } \\
\text { Chiku Monu ACC } & \text { laugh-ConjPrt hit-PERF } \\
\text { "Chiku hit Monu while he was laughing." }
\end{array}
$$

When conjunctive participles are placed in passives, objects - promoted/not promoted - are however unable to control their PRO subjects. Consider:

(24) a. ?sitaa $\left[\right.$ PRO $_{*} / *_{i m p}$ arg kaandikari ] gharu bidaa karaagalaa Sita crying-ConjPrt home send do-PFV "Having cried, Sita was sent from home."

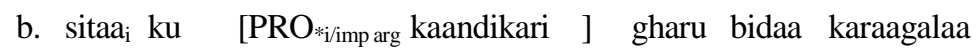
Sita ACC crying-ConjPrt home send do-PFV "Having cried, Sita was sent from home."

As (24a)-(24b) show, Sitaa, with or without the overt accusative case marker fails to control into the kari marked adjunct; the controller must instead be a subject. The conjunctive participle control test therefore suggests that the direct object is never in a subject position, though it could land up in a higher position. 


\subsection{Malayalam Active Passives}

Like the other Indian languages discussed above, Malayalam also has passives whose surface morphology suggests that the logical object has become the derived subject and the logical subject, with an instrumental marker, an adjunct. Compare the active with the passive in the following sentences.

(25) a. Jo:n raaman-e adicc-u

John Ram-ACC beat-PST

"John beat Ram."

b. raaman jo:n-in-aal adikka-ppett-u

Ram John-INSTR beat-PASS-PST

"Ram was beaten by John."

As with the other languages, anaphor binding is a good subject-hood diagnostic in this language. ${ }^{4}$ Here too, we find that the agentive by-phrase retains the subject-hood properties of the active subject. As illustrated in (26a)-(26b), both active and passive subjects A-bind reflexive DPs.
a. salmaa swandam $_{i}$ vi:tt-il tira-(y)um
Salma self-GEN house-LOC search-FUT
"Salma will search self's house."

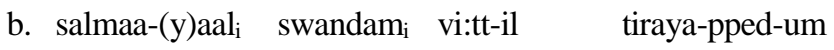
Salma-INSTR self-GEN house-LOC search-PASS-FUT
"Self's house will be searched by Salma."

Another diagnostic that can identify subjects in Malayalam is control. As we see below, both active subjects and agentive by-phrases in passives can control into complement clauses (27a)-(27b).
(27) a. salmaa ${ }_{i}\left[\mathrm{PRO}_{\mathrm{i}}\right.$ vitt-il po:kan] aagrahicc-u
Salma house-LOC go-INF wish-PST
"Salma wished to go home."
b. salmaa-(y)aal ${ }_{\mathrm{i}} \quad\left[\mathrm{PRO}_{\mathrm{i}}\right.$ vi:tt-il po:kan $]$ aagrahikka-ppett-u
Salma-INSTR house-LOC go-INF wish-PASS-PST
"By Salma was wished to go home."

What is unique about Malayalam passives is that their objects can never be marked overtly like their active objects (28a)-(28b).

${ }^{4}$ Anti-subject orientation is not a subject property in Malayalam. 
(28) a. naan kaduva-(y)e konn-u I tiger-ACC kill-PST "I killed the tiger."

b. kaduva enn-aal kolla-ppett-u tiger 1P.SG-INSTR kill-PASS-PST

"The tiger was killed by me."

Lack of overt case-marking may suggest that these objects are placed structurally lower, similar to what we observe for Hindi and Oriya. However, control facts suggest otherwise. Passive objects control into complement clauses in Malayalam as they do in the active counterparts, suggesting that they raise high enough to c-command other arguments. This is illustrated below in (29a)-(29b).
a. raaman $_{\mathrm{i}} \operatorname{mohan}_{\mathrm{j}-\mathrm{Od} \boldsymbol{}}\left[\mathrm{PRO} \boldsymbol{*}_{\mathrm{i} / \mathrm{j}}\right.$ vittil Raman Mohan-GEN "Raman asked Mohan to go home."
house-LOC go-INF say-PST
b. raaman-aal ${ }_{i}$ mohan $_{j}$-odə $\left[\mathrm{PRO} *_{\mathrm{i}_{j} \mathrm{j}}\right.$ vittil pokan] pəRə (y)ə-ppett-u Raman Mohan-GEN house-LOC
"By Raman, Mohan was asked to go home."

\section{go-INF say- NomPrt-PASS-PST}

\subsection{Kharia Active Passives}

Kharia too falls nicely in line with Hindi, Oriya and Malayalam when it comes to passives; i.e. its passives have typical SAL properties. Consider the data set given below (30a)-(30b), where an active and a passive are compared. The passive object is displaced to a sentence initial position, and the agent becomes optional.
(30) a. mili-ko raam te mahaa koley hinte taaro
Mili-ERG Ram-ACC big fight in kill-PST
"Milli killed Ram in the battle."
b. raam mahaa koley hinte ter-dom-ki
Ram big fight in kill-PASS-PST
"Ram was killed in the battle."

When realized, the agent is marked by the instrumental marker bung, as illustrated below.

$$
\begin{array}{lllll}
\text { mili yaa bung } & \text { raam mahaa } & \text { koley } & \text { hinte } & \text { ter-dom-ki } \\
\text { Milli-ERG by } & \text { Ram big fight in } & \text { kill-PASS-PST } \\
\text { "By Milli, Ram was killed in the battle." } & &
\end{array}
$$

The bung marked agent in Kharia behaves like active agents in different tests like anaphor binding, pronominal co-reference and control. Some relevant examples are given below. 
(32) a. salmaa aadiyaa $_{i}$ ohoh-yaa yonaa-kangnaa karaaye

Salma self house examine did

"Salma examined her own house."

b. salmaa $a_{i}$-yaa bung aadiyaa $a_{i}$ ohoh-yaa yonaa-kangnaa karaay- dom-ki

Salma-ERG by self house-GEN examine did- PASS-PST

"Self's house was examined by Salma."

Possessive reflexive binding is a subject property in Kharia as illustrated in (32a). The structure in (32b), which is a passive construction, similarly has the agentive phrase salmaa bung bind the possessive reflexive. Anti-subject orientation is another subject characteristic in Kharia. Once again, both active and passive agents obey this constraint, as (33a-33b) show.

(33) a. salmaa ${ }_{i}$ hokadaa*ijj ohoh-yaa yonaa-kongnaa karaay

Salma her house-GEN examine did

"Salma examined her house."

b. salmaa-yaa $a_{i}$ bung hokadaa $*_{i j}$ ohoh-yaa yonaa-kongnaa karaay-dom-naa Salma-ERG by her house-GEN examine did-PASS-PST "Her house was examined by Salma."

Kharia subjects can also control into complement clauses (34a). The agentive phrase in passives also behaves similarly in subject control construction (34b).

(34) a. salmaa ${ }^{2}\left[\mathrm{PRO}_{\mathrm{i}}\right.$ ohoh chonaa] laamnaa laa-kho

Salma house go want be-PST

"Salma wanted to go home."

b. salmaa-yaa $\mathrm{i}_{\mathrm{i}}$ bung [PRO $_{\mathrm{i}}$ ohoh chonaa] laam-dom-ki

Salma-ERG by house go want-PASS-PST

"By Salma was wanted to go home."

Apart from that, Kharia subjects can control into conjunctive participle adverbial clauses in Kharia (35a), a behavior mimicked by agentive phrases in passives (35b).

(35) a. salmaa ${ }_{\mathrm{i}}\left[\mathrm{PRO}_{\mathrm{i}}\right.$ ohoh chol-kon] mohan-te lene-ye

Salma house go-ConjPrt Mohan-ACC scold-FUT

"Salma will scold Mohan after going home."

b. salmaai-yaa bung $\left[\mathrm{PRO}_{\mathrm{i}}\right.$ ohoh chol-kon $]$ mohan te lene-dom-ki Salma-GEN by house go-ConjPrt Mohan-ACC scold-PASS-PST "Mohan will be scolded by Salma."

Passive objects also show object-like properties in the language. Firstly, accusative case-marking is obligatory for objects in passives. Non-case-marked objects yield ungrammaticality, as illustrated in the contrast between (36a)-(36b). 
(36) a. ing-te truth kong-dom-go-naa

I-ACC immediately identify-PASS-FUT

"I will be identified immediately."

b. *ing truth kong-dom-go-naa-ing

I-NOM immediately identify-PASS-FUT

"I will be identified immediately."

These case-marked DPs are placed high enough to c-command and control PRO in embedded clauses (37).

(37) raam-yaa bung mohan-te ${ }_{i} \quad\left[\mathrm{PRO}_{\mathrm{i}}\right.$ ohoh chonaa thong] gam-dom-ki Ram-ERG by Mohan-ACC house go for said-PASS-PST "Mohan was asked to go home by Ram."

But the promoted object is not placed high enough as the subject, as is confirmed by the fact that it obviates the anti-subject constraint (38).

(38) sitaa-yaa bung salmaa $\mathrm{i}_{\mathrm{i}}$ te hokadaa $\mathrm{i}_{\mathrm{i}}$ ohoh daang-dom-ki Sita-ERG by Salma-ACC her house send-PASS-PST "Salama was sent to her house by Sita."

\subsection{Summing up: The Spectrum of Passives}

SAL passives and their English counterparts are different as we have discussed above, yet they share one crucial feature: the underscoring of the agent. This underscoring or optionality, we suggest, is a crucial property of the passive voice, which has the unique ability of introducing an argument with a preposition. Preposition marking is what makes the argument appear like an optional adjunct. However, it is also interesting to note that though phonetically optional (in the sense of not getting overtly manifested obligatorily), passive agents are present in the structure as implicit arguments, an observation originally due to Bhatt and Pancheva (2006). Consider the following examples in this regard.

(39) The boat was sunk to collect the insurance.

(40) The boat was sunk deliberately.

As illustrated above, the PRO of the embedded clause (39) needs a controller, which is the implicit agent. Similarly in (40), an agent-oriented adverbial is allowed because of the presence of an implicit agent. SALs display similar behavior (41)-(42).

(41) nauke-ko bimaa lene ke liye duboyaa gayaa boat-ACC insurance collect for sink go-PFV

"The boat was sunk to collect the insurance"

(42) nauke-ko jaanbhujkar duboyaa gayaa

boat-ACC deliberately sink go-PFV

"The boat was sunk deliberately." 
That indicates that the optionality of the agent is a matter of phonetics, not syntax. Passive agents are just like any other argument of the structure; they are obligatory hosted in the syntax. Whether they appear ultimately to the subject position or not differ from one language to the other, a difference possibly determined by other systemic concerns.

Secondly, if we are right, there is an entire spectrum of passive constructions, some of which obey only the minimal condition for passives - the underscoring of agents, and others which have additional features of object topicalization/promotion and/or verbal morphology alternations. English is a language that has all three properties, whereas SALs discussed here have only two of them - agent underscoring and change in verbal morphology. Tibeto-Burman languages may have passives that have agent underscoring and object topicalization, but no verbal morphology alternations. We detail on passives from this family of languages in the next section.

\section{The Tibeto-Burman Passive}

Whether Tibeto-Burman languages like Ao and Manipuri host passives is a contentious issue since there is no separate passive verbal morphology nor are agents marked with prepositions like "by" or "with". Actives do have some counterparts with dropped agents and topicalized objects quite reminiscent of passives, but additional evidence is called for before we can confidently make any such claim. Take some sentences below for illustration.

(43) a. john-i kaari kaa aali

John car one buy-PFT

"John bought a car."

b. kaari kaa (john-i) aali

car one John buy-PFT-PASS

"A car was bought by John."

(44) a. police.tu.naa nay phugani

police-DEF you beat-FUT

(Manipuri)

"The policeman will hit you."

b. (police.tu.naa) nan.bu phugani

police-DEF you-DEF beat-FUT

"You will be hit by the policeman."

In both Ao and Manipuri, agent underscoring is possible in some constructions, such as (43b) and (44b); compare these with the (a) sentences where agents are a must. The objects in the optional agent-constructions are also highlighted by either their sentence-initial positions or by a definiteness marker respectively. Ao also has objects marked distinctly with the definiteness particle ji or yaa with the agents suppressed. This is illustrated in (45)-(46). 
(45) a. parnoki tanur yaashi aangu They child yesterday see/find-PFV

"They saw/found the child yesterday."

b. Tanur-ji yaashi tesusaa aangu child-def. yesterday last see/find-PFV

"The child was last seen yesterday."

(46) a. window-yaa nisung aa-i aaksaa window-def. person someone broke

"The window was broken by someone."

Similarly, Manipuri (see the contrast in (47a) and (47b)) can use the sentenceinitial position to highlight the object.

(47) a. joan-naa meri-bu phure

Joan-DEF Mary-DEF hit-PFV

"Joan hit Mary."

b. meri-bu joan-naa phukhre/phure

Mary-DEF Joan-DEF hit-PFV

"Mary was hit by Joan."

In short, we find these languages using either the sentence-initial position or a special morpheme to mark the most prominent, non-subject argument. In contrast, actives with ergative subjects occupy the sentence-initial position, but there is no special marking for them. Special marking seems restricted for non-subject arguments. This is the initial indication that these are not true actives. Moreover, the topicalized objects are placed high enough to control into complement clauses (see (48b) and (49b); contrast them with the active sentences with subject control in the (a) sentences.

(48) a. na-yaa (sepaai) azuktsa insurance bentba yong you-def. policeman hit insurance collection for "You will be hit by the policeman to collect the insurance."

b. sepaai-naa na azuktsa insurance bentsu aatemaa policeman you hit insurance collect purpose "The policeman will hit you to collect the insurance."

(49) a. insurance khomnaabaa naangbu phugani insurance collect you hit.will

(Manipuri)

"You will be hit to collect the insurance."

b. pulisnaa naangbu phuragaa insurance khomgani police you hit insurance collect

"The police will hit you to collect the insurance."

Interestingly, both languages can use agent-oriented adverbials with these optional agent-sentences. Consider: 
(50) a. sepaai teloktem aashaa-tang mitsi-tok

policeman protestor deliberately kick-PFV

"The policeman kicked the protestor deliberately."

b. teloktem-ji (sepaai) aashaa-tang mitsi-tho protestor-def. policeman deliberately kick

"The protestor was kicked deliberately (by the policeman)."

(51) a. pulisnaa protestardo thauojna kawkhi

(Manipuri)

policeman protestor deliberately kick

"The policeman kicked the protestor deliberately."

b. protestardo thauojna kawkhi

protestor deliberately kicked

"The protestor was deliberately kicked."

Such sentences with agent-oriented adverbials suggest that like passives in other languages, the agents in Ao and Manipuri, even when they are phonetically absent or removed from their canonical sentence-prominent positions, are syntactically active. They are implicit arguments when not phonetically represented.

Moreover, like other passives (English (52)), Ao and Manipuri prevent these constructions from hosting "from" agentive phrases (53)-(54) respectively.

(52) *The man was killed from the car.

(53) *tanur-ji sepaai-e mitsi-tok

Child-def. policeman-from kicked

"The child was kicked from the police."

(54) *angando kawkhi pulistagi

Child kicked police-from

"The child was kicked from the police."

A final piece of evidence to show that these optional agent-less constructions are actually passives is their semantics with negation. It is observed that with Ao sentences like (55), the presence of a negation imparts it a non-stative reading. The sentence is interpreted as the beans not having put to boil at all by an agent; there is no reference to a state of the beans being half-boiled. On the other hand, a stative interpretation is possible for (56).

(55) Beans-yaa ano me-molaa

Beans-def still not-boiled

"The beans have not been put to boil"

(56) Beans-yaa chonga me-molaa

Bean-def. well not-boiled

"The beans are not well-cooked"

The interesting difference between the two is that only in the former - with the non-stative meaning, can one have an optional agentive by-phrase phonetically 
represented, whereas the one with the stative meaning completely rejects the presence of an agent. This suggests that the former is a passive and the latter a stative. ${ }^{5}$

Manipuri on the other hand prefers a stative meaning with such constructions (57). As expected, agentive phrases are ruled out here.

(57) Hawaaido munde

Beans not-cooked

"The beans are not well-cooked"

We thus have some substantial piece of evidence for suggesting that active looking constructions in Ao and Manipuri with optionally dropped agents and topicalized objects are indeed passives. Lack of separate passive verbal morphology suggest otherwise, but we have illustrated here that the properties of actives - like projecting agents as most prominent arguments or subjects as well as controlling into complement clauses - are not found in these agentless constructions. Moreover, the latter allow agent-oriented adverbs while disallowing from-agentive phrases, two properties that we also observe with English passives. Similarly, only passives with non-stative readings allow optional agents, whereas statives don't. Suppression of agents therefore seems to be a property unique to passives in these languages as well.

\section{Conclusion: A way out for Universalism}

Our study shows that cross-linguistically passives manifest different surface properties. English passives are recognized by optional agent suppression, object to subject movement and separate verbal morphology, whereas languages like Hindi, Oriya, Kharia and Malayalam have passives with optional agent suppression and separate verbal morphology, but no object movement to subject position. Finally, Ao and Manipuri passives optionally suppress their agents and have object movement, but do not host separate verbal morphology. There is then one crucial property that all passives in the languages under study share and that is the suppression or underscoring of the agent. They therefore obey Shibatani's minimal condition for passives. We can therefore safely conclude that there is a universal passive voice - with its ability to underscore the agent - underlying every language. This paper is therefore a defense of “categorical universalism" over Haspelmath's proposed "categorical particularism".

Haspelmath through his emphasis on categorical particularism proposes a radical disconnect between grammatical analyses of particular-languages and cross-linguistic

${ }^{5}$ Dubinsky and Simango (1996) find a similar semantic distinction between passives and statives in Chichewa illustrated through the following examples. Passives in this language, unlike Ao and Manipuri however have a distinct passive morphology.

(i) Nyemba si-zi-na-phik-idwe

Beans neg-agr-past-cook-pass

"The beans were not cooked (at all)."

(ii) Nyemba si-zi-na-phik-ike

Beans neg-agr-past-cook-stat

"The beans were not cooked (well)." 
typological studies. "Each language has its own categories, ...[which] are often similar across languages, but the similarities and differences between languages cannot be captured by equating categories across languages" (Haspelmath, 2007, p. 663). Typology is therefore considered beyond the reach of language-particular theoretical researches.

We suspect otherwise, given what we observe in the paper. One crucial property that we find for every passive in well-studied languages such as English is agent suppression. This property is then isolated and investigated on novel data from a set of chosen languages. It is observed in all these constructions, which force us to contend that they are indeed all of the same type even though some of them may manifest extra features and surface morphology. Our search therefore leads us from languageparticular properties to significant typological generalizations, indicating that the disconnect Haspelmath tries to build between these two strands of research is faulty to start with. Language particular theoretical analyses and typology go hand in hand to a large extent; they feed into each other.

We therefore find it appropriate to end our paper with an observation due to Newmeyer (2010, p. 688), "universal comparative concepts and language-particular descriptive categories are each highly problematic in and of themselves. It is only by means of working out the interplay between the language-particular and the languageindependent that we can hope to understand either".

\section{References}

Afarli, T. A. (1989). Passive in Norwegian and in English. Linguistic Inquiry 20(1), 101-108.

Baker, M. C. (1988). Incorporation: A Theory of grammatical function changing. Chicago: University of Chicago Press.

Baker, M. C. (2003). Lexical categories: Verbs, nouns and adjectives. Cambridge: Cambridge University Press.

Baker, M. C. (2009). Language Universals: Abstract not Mythological. Behavior and Brain Sciences, 32, 448-449.

Baker, M., Johnson, K. \& Roberts, I. (1989). Passive arguments raised. Linguistic Inquiry, 20, 219-251.

Bhatt, R. (2003). Topics in the Syntax of the Modern Indo-Aryan Languages. (Passivization Handout) URL: http://web.mit.edu/rbhatt/www/24.956

Bhatt, R., \& Pancheva, R. (2006). Implicit Arguments. In The Blackwell Companion to Syntax Vol. II, 554-584. Wiley-Blackwell.

Collins, C. (2005). A Smuggling Approach to the Passive in English. Syntax, 8, 81-120.

Comrie, B. (1989). Language Universals and Linguistic Typology. 2nd ed. Oxford: Blackwell.

Corbett, G. G. (2000). Number. Cambridge: Cambridge University Press.

Dixon, R. M. W. (2004). Adjective classes in typological perspective. In Adjective classes: a cross-linguistic typology; R. M. W. Dixon, and Alexandra Y. Aikhenvald (Eds.), 30-83. Oxford: Oxford University Press.

Dixon, R. M. W. (2010). Basic Linguistic Theory. Vol. 1-2. Oxford: Oxford University Press.

Dubinsky, S., \& Simango, S. R. (1996). Passive and Stative in Chichewa: Evidence for Modular Distinctions in Grammar. Language, 72(4), 749-781. 
Gehrke, B., \& Grillo, N. (2009). How to become passive. In Explorations of Phase Theory: Features, Arguments and Intrerpretation at the Interfaces; K. K. Grohmann (Ed.). Berlin/New York: de Gruyter.

Givon, T. (1979). On understanding grammar. New York: Academic Press.

Granger, S. (1983). The be + past participle construction in spoken English with special emphasis on the passive. Holland Linguistic Series 49. Amsterdam, New York \& Oxford North: Elsevier.

Haspelmath, M. (2007). Pre-established categories don't exist: consequences for language description and typology. Linguistic Typology, 11(1), 119-132.

Haspelmath, M. (2010). Comparative concepts and descriptive categories in cross-linguistic studies. Language, 86(3), 663-687.

Keenan, E. L. (1976). The Logical diversity of natural languages. In Origin and Evolution of Language and Speech. New York: Academy of Sciences.

Mahajan, A. (1994). Active Passives. In Proceedings of the Thirteenth West Coast Conference on Formal Linguistics; R. Aronovich, W. Byrne, S. Preuss, and M. Senturia (Eds.). Stanford University: CSLI Publications.

Newmeyer, F. J. (2007). Linguistic typology requires cross linguistic formal categories. Linguistic Typology, 11, 133-157.

Newmeyer, F. J. (2010). On Comparative Concepts and Descriptive Categories: A Reply to Haspelmath. Language, 86, 688-695.

Payne, T E. (1997). Describing morphosyntax: A guide for field linguists, Cambridge: Cambridge University Press.

Richa (2011). Hindi Verb Classes and their Argument Structure Alternations. UK: Cambridge Scholars Publishers.

Roberts, I. (2008). Smuggling, Affectness and Argument Structure Alternation. Ms. University of Cambridge.

Shibatani, M. (1985). Passives and related constructions: a prototype analysis. Language, 61, 821-848.

Shibatani, M. (2006). On the conceptual framework for voice phenomena. Linguistics, 44, $217-$ 269.

Siewierska, A. (1984). Passive: A Comparative Linguistic Analysis. London: Routledge

Siewierska, A. (2005). Passive constructions. In M. Haspelmath, M. Dryer, D. Gil, \& B. Comrie (Eds.)., World Atlas of Linguistic Structures. Oxford: Oxford University Press.

Slavutych, Y. (1973). Conversational Ukrainian. Edmonton: Gateway.

Van Valin, R. D. Jr. (2005). Exploring the syntax-semantic interface. Cambridge: Cambridge University Press. 